\title{
Pemanfaatan Minyak Atsiri Daun Sirih (Piper Betle Linn) Sebagai Anti Nyamuk
}

\author{
Deki Gunawan ${ }^{1}$, Rina Kurniaty ${ }^{2, *}$ \\ ${ }^{1}$ Akademi Farmasi Poltekkes Kemenkes Aceh, Banda Aceh, Indonesia \\ ${ }^{2}$ Akademi Farmasi YPPM, Banda Aceh, Indonesia \\ Email: 2,"rinaothee@ gmail.com
}

\begin{abstract}
Abstrak-Daun sirih (Piper betle Linn) merupakan tanaman yang dikenal luas oleh masyarakat Indonesia, memiliki kandungan senyawa fenol dan derivatnya yang mencapai 30\% pada ekstrak maupun minyak atsiri, dan pada konsentrasi 100 ppm dapat membunuh larva nyamuk berdasarkan aktivitas insektisida. Penelitian ini bertujuan untuk memanfaatkan minyak atsiri daun sirih, yang diperoleh secara metode destilasi uap air dalam bentuk sediaan semprot dan mengetahui pada konsentrasi berapakah minyak atsiri daun sirih tersebut dapat digunakan sebagai anti nyamuk. Penelitian ini bersifat ekperimental laboratorium, sediaan semprot anti nyamuk di buat sebanyak 3 formula (F1, F2 dan F3) dengan konsentrasi 13\%, 15\%, dan 17\%. Pengujian yang di lakukan terhadap sediaan semprot anti nyamuk adalah uji organoleptis dan uji efektifitas dari sediaan terhadap sepuluh ekor nyamuk dewasa. Sediaan semprot anti nyamuk dengan konsentrasi minyak atsiri daun sirih $17 \%$ yang lebih efektif terhadap mengusir dan membunuh nyamuk. Penelitian selanjutnya dapat mengembangkan pemanfaatan minyak atsiri daun sirih dengan variasi konsentrasi yang berbeda, atau kombinasi dengan bahan aktif lain sebagai anti nyamuk.
\end{abstract}

Kata Kunci: Minyak Atsiri; Daun Sirih; Anti Nyamuk

Abstract-Betel leaf (Piper betle Linn) is a plant that is widely known by the people of Indonesia, contains phenolic compounds and their derivatives which reaches $30 \%$ in extracts and essential oils, and at a concentration of $100 \mathrm{ppm}$ it can kill mosquito larvae based on insecticidal activity. This study aims to utilize betel leaf essential oil, which was obtained by steam distillation method in the form of a spray dosage form and to find out at what concentration the betel leaf essential oil can be used as an insect repellent. This research is a laboratory experiment, there are 3 formulas of mosquito repellent spray (F1, F2 and F3) with a concentration of 13\%, $15 \%$, and $17 \%$. The tests carried out on the anti-mosquito spray preparation were organoleptic tests and tests the effectiveness of the preparations against ten adult mosquitoes. Anti-mosquito spray preparation with a concentration of $17 \%$ betel leaf essential oil which is more effective at repelling and killing mosquitoes. Further research can develop the use of betel leaf essential oil with variations in different concentrations, or in combination with other active ingredients as mosquito repellent.

Keywords: Essential Oil; Betel Leaf; Anti Mosquito

\section{PENDAHULUAN}

Daun sirih (Piper betle Linn) secara tradisional dapat digunakan untuk mengatasi bau badan, bau mulut, sariawan, mimisan, gatal-gatal, mengobati keputihan dan insektisida alami. Penelitian sebelumnya tentang manfaat dari daun sirih oleh Harsel (1948), menunjukkan bahwa ekstrak etanol daun sirih dengan konsentrasi 100 ppm dapat membunuh larva nyamuk. Aktivitas ini disebabkan adanya kandungan senyawa fenol dan derivatnya yang mencapai 30\% pada ekstrak dan minyak atsiri dari daun sirih.

Nyamuk merupakan serangga yang menjadi faktor utama dalam penularan penyakit. Terdapat banyak jenis nyamuk yang mampu menyebabkan penyakit pada manusia antara lain nyamuk Anophles penyebab penyakit malaria, nyamuk Culex sp, Mansonia sp, Aedes sp, dan Anopheles sp penyebab penyakit filariasi/kaki gajah, nyamuk Ades aegypti, Aedes albopictus, Culex sp, dan Mansonia sp penyebab penyakit chikungunya dan nyamuk Aedes aegypti penyebab penyakit demam berdarah. Beberapa upaya dilakukan untuk mencegah penyakit tersebut, diantaranya dengan pengendalian nyamuk itu sendiri maupun perlindungan terhadap gigitan nyamuk, diantaranya dengan memasang kawat kasa pada jendela rumah, memasang kelambu tidur, menggunakan obat nyamuk dengan cara di oles, semprot, bakar, dan elektrik.

Pemanfaatan daun sirih dikalangan masyarakat dengan salah satu kandungan zat aktifnya dapat dijadikan sebagai anti nyamuk. Pada sejumlah penelitian daun sirih mengandung 1-4,2\% minyak atsiri, hidroksikavikol, 7,2-16,7\% kavikol, 2,7-6,2\% kavibetol, 0-9,6\% allylpyrokatekol; 2,2-5,6\% karvakol; 26,8-42,5\% eugenol; 4,2- 15,8\% eugenol metil eter; 1,2-2,5\% p-cymene; 2,4-4,8\% cyneole; 3-9,8\% caryophyllene; dan 2,4-15,8\% caddinene, selain itu juga mengandung estragol, terpennena, seskuiterpena, fenil propana, tanin, diastase, gula, dan pati. Minyak atsiri adalah zat cair yang mudah menguap dan dapat dihasilkan dengan cara penyulingan, ekstraksi dengan pelarut menguap, ekstraksi dengan lemak dingin, ekstraksi dengan lemak panas (maserasi) dan pengepresan. Daun sirih yang digunakan dalam keadaan segar dan murni tanpa pencemaran, minyak atsiri yang diperoleh umumnya tidak berwarna. Namun, pada penyimpanan lama minyak atsiri dapat berubah warnanya menjadi lebih tua (gelap).

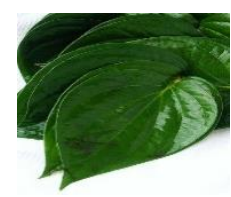

Gambar 1. Daun Sirih (Piper betle Linn) 


\section{METODOLOGI PENELITIAN}

\subsection{Alat dan Bahan}

Alat yang digunakan yaitu seperangkat alat destilasi, botol semprot yang bagian atasnya sudah terdapat pompa, beaker glass, timbangan digital, gelas ukur, erlenmeyer, corong pisah, dan kandang pengujian nyamuk. Bahan-bahan yang digunakan yaitu minyak atsiri dari daun sirih (Piper betle Linn), alkohol 70\%, aquadest.

\subsection{Pengumpulan dan Penyiapan Simplisia Segar}

Simplisia yang digunakan adalah Daun sirih segar berwarna hijau (Piper betle Linn) dari Pemukiman Rawa Sakti, Kecamatan Susoh Aceh Barat Daya.

\subsection{Proses Isolasi Minyak Atsiri}

$15 \mathrm{~kg}$ daun sirih segar di cuci bersih dan di jemur dibawah matahari selama tiga hari, didapat daun sirih yang sudah kering $6 \mathrm{~kg}$ dan dipotong kecil-kecil dengan menggunakan gunting, kemudian dimasukkan ke lapisan atas bejana alat penyulingan dan pada lapisan bawah bejana telah diisi air. Selanjutnya alat penyulingan ditekan tombol on dan ditunggu sampai air mendidih, setelah mencapai $100^{\circ} \mathrm{C}$ dimasukkan kedalam bejana yang telah berisi potongan daun sirih yang sudah siap untuk disuling. Ketika air mendidih, uap air akan membawa partikel-partikel minyak atsiri daun sirih ke bagian kondensor. Selanjutnya, uap air bersama komponen minyak di tampung dalam wadah yang tertutup. Dimasukkan minyak atsiri yang di peroleh dari penyulingan kedalam corong pemisah untuk memisahkan minyak atsiri dengan air, penyulingan dilakukan sampai tetesan minyak atsiri pada penampung sudah tidak menetes lagi (5 jam penyulingan).

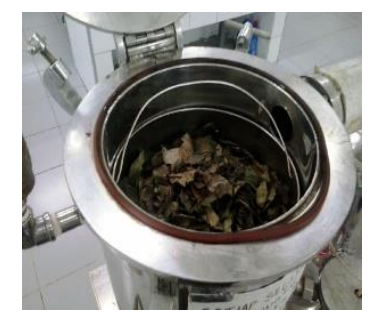

Gambar 2. Proses Penyulingan (Destilasi)

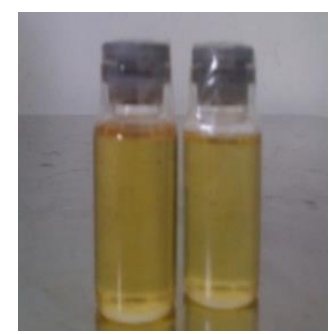

Gambar 3. Minyak Atsiri Daun Sirih

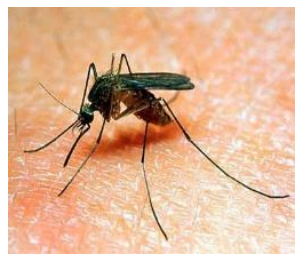

Gambar 4. Nyamuk Culex quinquifasciatus Say

Tabel 1. Komposisi Sediaan Anti Nyamuk ${ }^{5}$

\begin{tabular}{ccccc}
\hline \multirow{2}{*}{ No } & Bahan & \multicolumn{3}{c}{ Formula (\% v/v) } \\
& & I & II & III \\
& & $13 \%$ & $15 \%$ & $17 \%$ \\
\hline 1. & Minyak Atsiri Daun Sirih & 6,5 & 7,5 & 8,5 \\
2. & Alkohol 70\% ad & 50 & 50 & 50 \\
\hline
\end{tabular}

\subsection{Pembuatan Formula Anti Nyamuk}




\section{Journal of Pharmaceutical and Health Research}

\section{Vol 2, No 2, Juni 2021, pp. 46-49}

ISSN 2721-0715 (media online)

DOI 10.47065/jharma.v2i2.862

Proses pembuatan formula anti nyamuk di awali dengan menyiapkan semua bahan sesuai yang tertera di tabel 1 dan dikalibrasi botol. Sebagian alkohol 70\% dimasukkan kedalam botol semprot, kemudian ditambahkan minyak atsiri ke dalam botol semprot lalu di kocok sampai tercampur, kemudian ditambahkan lagi sisa alkohol $70 \%$ sampai $50 \mathrm{~mL}$, di tutup botol, kocok sampai tercampur.

\subsection{Uji Evaluasi Sediaan Anti Nyamuk}

Setelah sediaan anti nyamuk selesai di formulasi maka akan dilakukan evaluasi sediaan selama 7 hari pada hari pertama, ketiga, kelima, dan ketujuh, untuk uji efektifitas sediaan hanya dilakukan pada hari pertama dan hari ketujuh.

\section{Uji organoleptis}

Uji organoleptis dilakukan dengan melihat tampilan fisik sediaan dengan cara melakukan pengamatan terhadap warna, dan bau dari sediaan yang telah di buat.

\section{Uji efektifitas sediaan anti nyamuk}

Uji efektifitas sediaan dilakukan dengan cara di semprotkan sediaan anti nyamuk pada sebuah kain yang kemudian ditempelkan dalam setiap kotak pengujian dengan ukuran 40x50 cm, kemudian 10 ekor nyamuk dilepaskan ke dalam masing-masing kotak. Penilaian dilakukan dengan pengamatan dan pencatatan waktu pada menit keberapa nyamuk hinggap dan pergi, pengujian sediaan dilakukan selama 60 menit, hal yang sama dilakukan terhadap pengujian kontrol dengan mengunakan alkohol $70 \%$.

\section{HASIL DAN PEMBAHASAN}

Proses pembuatan minyak atsiri daun sirih dilakukan dengan cara destilasi daun sirih menggunakan metode destilasi uap air, pada proses pertama dilakukan pemilihan daun sirih yang berwarna hijau dengan tujuan agar menghasilkan minyak atsiri yang berkualitas. Pemilihan cara destilasi ini karena keuntungan metodenya, yaitu dengan penetrasi uap terjadi secara merata ke dalam jaringan bahan dan suhu dapat dipertahankan sampai $100^{\circ} \mathrm{C}$ dan proses penyulingan relatif lebih singkat serta rendemen minyak yang diperoleh lebih baik jika dibandingkan dengan minyak hasil sistem penyulingan dengan air. Hasil yang didapat dimasukkan kedalam botol vial dan ditambahkan serbuk $\mathrm{N}_{\mathrm{a} 2} \mathrm{SO}_{4}$ yang bertujuan untuk memisahkan dan menghilangkan endapan atau sisa kotoran di saat penyulingan, dimana setiap sekali dilakukan penyulingan minyak atsiri yang diperoleh $1,5 \mathrm{~mL}$.

Minyak atsiri daun sirih selanjutnya di lakukan pembuatan sediaan anti nyamuk dengan tiga formula, $13 \%(6,5$ $\mathrm{mL}), 15 \%(7,5 \mathrm{~mL})$ dan $17 \%(8,5 \mathrm{~mL})$, kemudian ditambahkan dengan alkohol $70 \%$ sampai tanda batas. Selanjutnya dilakukan uji organoleptis dan uji efektifitas anti nyamuk. Uji organoleptis dilakukan untuk melihat tampilan dari fisik sediaan dengan melakukan pengamatan terhadap bentuk, warna dan bau pada setiap sediaan, uji organoleptis pada penelitian ini di lakukan pada hari pertama, ketiga, kelima dan hari ketujuh pengamatan, dan setiap sediaan di lakukan pengujian efektifitas sebagai sediaan anti nyamuk yang dilakukan pada hari pertama dan ketujuh pengamatan dengan menggunakan 10 ekor nyamuk dewasa.

Tabel 2. Hasil Uji Organoleptis Sediaan Anti Nyamuk

\begin{tabular}{|c|c|c|c|}
\hline \multirow{2}{*}{ Formula } & \multicolumn{3}{|c|}{ Organoleptis } \\
\hline & Warna & Bau & Bentuk \\
\hline \multicolumn{4}{|l|}{ Hari Ke-1 } \\
\hline $\mathrm{I}(13 \%)$ & Kuning bening & khas daun sirih & Cair \\
\hline II $(15 \%)$ & Kuning bening & khas daun sirih & Cair \\
\hline III $(17 \%)$ & Kuning bening & khas daun sirih & Cair \\
\hline \multicolumn{4}{|c|}{ Hari Ke-3 s/d Hari ke-7 } \\
\hline I $(13 \%)$ & $\begin{array}{l}\text { Kuning bening ada endapan, bila di } \\
\text { kocok tercampur sempurna kembali }\end{array}$ & khas daun sirih & Cair \\
\hline II $(15 \%)$ & $\begin{array}{l}\text { Kuning bening ada endapan, bila di } \\
\text { kocok tercampur sempurna kembali }\end{array}$ & khas daun sirih & Cair \\
\hline III $(17 \%)$ & $\begin{array}{l}\text { Kuning bening ada endapan, bila di } \\
\text { kocok tercampur sempurna kembali }\end{array}$ & khas daun sirih & Cair \\
\hline
\end{tabular}

Tabel 3. Hasil Pengamatan Uji Efektifitas Sediaan Anti Nyamuk

\begin{tabular}{cccccc}
\hline Sediaan & $\begin{array}{c}\text { Jumlah nyamuk } \\
\text { yang hinggap } \\
\text { (ekor) }\end{array}$ & $\begin{array}{c}\text { Hinggap pada } \\
\text { menit ke }\end{array}$ & $\begin{array}{c}\text { Lama nyamuk } \\
\text { hinggap }\end{array}$ & $\begin{array}{c}\text { Jumlah } \\
\text { nyamuk yang } \\
\text { mati (ekor) }\end{array}$ & $\begin{array}{c}\text { Mati pada } \\
\text { menit ke }\end{array}$ \\
\hline Hari Ke-1 & & & & & \\
\hline $\mathrm{I}(13 \%)$ & 1 & 6 & 1 detik & & 43 \\
\hline
\end{tabular}


Journal of Pharmaceutical and Health Research

Vol 2, No 2, Juni 2021, pp. 46-49

ISSN 2721-0715 (media online)

DOI 10.47065/jharma.v2i2.862

\begin{tabular}{|c|c|c|c|c|c|}
\hline Sediaan & $\begin{array}{c}\text { Jumlah nyamuk } \\
\text { yang hinggap } \\
\text { (ekor) }\end{array}$ & $\begin{array}{l}\text { Hinggap pada } \\
\text { menit ke }\end{array}$ & $\begin{array}{l}\text { Lama nyamuk } \\
\text { hinggap }\end{array}$ & $\begin{array}{c}\text { Jumlah } \\
\text { nyamuk yang } \\
\text { mati (ekor) }\end{array}$ & $\begin{array}{l}\text { Mati pada } \\
\text { menit ke }\end{array}$ \\
\hline & 1 & 28 & 1 detik & & \\
\hline II $(15 \%)$ & 3 & 15 & 1 detik & 5 & $\begin{array}{l}2 \text { ekor menit } 29 \text {, } \\
\text { dan } 3 \text { ekor menit } 34\end{array}$ \\
\hline III (17\%) & 1 & 28 & 1 detik & 8 & $\begin{array}{c}3 \text { ekor menit } 18,2 \\
\text { ekor menit } 29 \text {, dan } \\
3 \text { ekor menit } 38\end{array}$ \\
\hline \multicolumn{6}{|l|}{ Hari Ke-7 } \\
\hline \multirow[t]{2}{*}{ I (13\%) } & 1 & 8 & & \multirow[t]{2}{*}{2} & \multirow[t]{2}{*}{$\begin{array}{l}1 \text { ekor menit } 40 \text { dan } \\
1 \text { ekor menit } 42\end{array}$} \\
\hline & 2 & 15 & 1 detik & & \\
\hline II (15\%) & 3 & 27 & 1 detik & 5 & $\begin{array}{c}2 \text { ekor menit } 29 \text {, } \\
\text { dan } 3 \text { ekor menit } 34\end{array}$ \\
\hline III $(17 \%)$ & - & - & - & 8 & $\begin{array}{c}2 \text { ekor menit } 19,2 \\
\text { ekor menit } 29, \text { dan } \\
4 \text { ekor menit } 39\end{array}$ \\
\hline
\end{tabular}

Uji efektifitas pada hari pertama di lakukan pada 3 sediaan anti nyamuk 13\%, 15\% dan 17\% yang di semprotkan pada kain hitam yang akan di tempelkan pada kotak pengujiaan, kemudian dilepaskan 10 ekor nyamuk dewasa dan di lakukan pengamatan selama 60 menit (lakukan pencatatan waktu nyamuk hinggap dan pergi pada kain tersebut). Nyamuk yang di gunakan pada 3 sediaan anti nyamuk berbeda pada masing-masing kotak pengujian, hal yang sama juga dilakukan pada hari ke tujuh pengamatan.

Dari hasil pengamatan selama 7 hari, di hari pertama sediaan I (13\%) dihinggapi 1ekor nyamuk pada menit 6, 3 dan pada menit 15, dan 1 pada menit 28 serta 2 ekor nyamuk mati pada menit 43, sediaan II (15\%) di hinggapi 3 nyamuk pada menit 25 dan 5 ekor nyamuk mati pada menit 29 mati 2 ekor nyamuk, 3 ekor di menit 34, sedangkan sediaan III (17\%) di hari pertama 1 nyamuk pada menit 40 dan 8 ekor nyamuk mati, 3 mati di menit 18, 2 ekor di menit 29 dan 3 di menit 38. Sedangkan untuk hasil pengamatan di hari ketujuh sediaan I (13\%0 di hinggapi 1 ekor nyamuk di menit 2, 2 di menit di menit 15, dan 2 ekor nyamuk yang mati, 1 ekor di menit 40, 1 ekor menit 42 . Sediaan II (15\%) 3 ekor nyamuk yang hinggap pada menit 27 dan 2 mati pada menit 39 serta 3 di menit 34, sedangkan sediaan III (17\%) di hari ketujuh penelitian tidak di hinggapi satu ekor nyamuk dan 8 ekor nyamuk mati, 2 ekor di menit 19, 2 di menit 29 dan 4 ekor nyamuk mati di menit 39.

\section{KESIMPULAN}

Berdasarkan hasil penelitian dapat disimpulkan bahwa formulasi sediaan anti nyamuk dengan menggunakan bahan aktif minyak atsiri daun sirih (Piper betle Linn) efektif mengusir nyamuk, semakin tinggi konsentrasi yang digunakan maka semakin efektif sebagai pengusir nyamuk dengan konsentrasi paling tinggi 17\%, di mana di hari pertama pegamatan uji efektifitas di hinggapi satu ekor nyamuk dan delapan ekor mati sedangkan di hari ketujuh pengamatan tidak di hinggapi satu ekorpun oleh nyamuk serta delapan ekor nyamuk yang mati. Pada penelitian selanjutnya perlu dilakukan pemanfaatan dari minyak atsiri daun sirih dalam bentuk sediaan lain dalam bidang farmasi.

\section{DAFTAR PUSTAKA}

Oka, Adi Parwata, dkk. 2011. Aktivitas Larvasida Minyak Atsiri Pada Daun Sirih (Piper Betle Linn) Terhadap Larva Nyamuk Aedes aegypti. Jurnal. Denpasar: Laboratorium Organik Jurusan Kimia FMIPA Universitas Udayana.

Hariana, Arief. 2011. Tumbuhan Obat Dan Khasiatnya. Depok: Swadaya.

Armando, Rochim. 2009. Memproduksi 15 Minyak Atsiri Berkualitas. Jakarta: Penebar Swadaya.

Wiyanti, C Disya. 2013. Formulasi Dan Evaluasi Sediaan Gel Anti Nyamuk Dari Minyak Zodia (Evodia Suaveolens Scheff). Skripsi. Bandung: Fakultas Farmasi Universitas Jenderal Achmad Yani Cimahi.

Widiani, ni putu pitri dan Kartini. 2011. Formulasi Dan Uji Aktifitas Minyak Legundi (Vitex trifolia L) Sebagai Sediaan Anti Nyamuk. Akademi Farmasi Putra Indonesia Malang.

Soekarto, S. T. Penilaian Organoleptis. Departemen Pendidikan dan Kebudayaan Direktorat Jendral Pendidikan Tinggi. Pusat Antar Universitas. Bogor: IPB

Koensoemardiyah. 2010. A to Z Minyak Atsiri Untuk Industry Makanan, Kosmetik, dan Aromaterapi. Andi. Yogyakarta.

Ngaisah, Siti. 2010. Identifikasi dan Uji Aktivitas Anti Bakteri Minyak Atsiri Daun Sirih Merah (Piper Crocatum Ruiz \& Pav). Skripsi. Surakarta: Fakultas Matematika Dan ilmu Pengetahuan Alam Universitas Sebelas Maret. 